\title{
The spider families Synotaxidae and Malkaridae (Arachnida: Araneae: Araneoidea) in Western Australia
}

\author{
Michael G. Rix ${ }^{1,2}$, J. Dale Roberts ${ }^{1}$ and Mark S. Harvey ${ }^{2,1}$ \\ ${ }^{1}$ School of Animal Biology M092, University of Western Australia, \\ 35 Stirling Highway, Crawley, Perth, Western Australia 6009, Australia \\ E-mail: droberts@cyllene.uwa.edu.au. \\ ${ }^{2}$ Department of Terrestrial Zoology, Western Australian Museum, Locked Bag 49, \\ Welshpool D.C., Perth, Western Australia 6986, Australia \\ E-mail: michael.rix@musuem.wa.gov.au; mark.harvey@museum.wa.gov.au
}

\begin{abstract}
The southern-temperate spider families Synotaxidae and Malkaridae are newly recorded from south-western Western Australia, each for a new species from the eastern Stirling Range National Park. The synotaxid genus Calcarsynotaxus Wunderlich, previously described from south-eastern Queensland, is represented in Western Australia by the new species C. benrobertsi. The sternoidine malkarid genus Perissopmeros Butler, previously described from south-eastern Australia, is represented in Western Australia by the new species P. darwini. Species of Synotaxidae and Malkaridae are rare and highly restricted in south-western Australia, known only from refugial, mesic habitats in montane areas of the Stirling Range National Park.
\end{abstract}

\section{INTRODUCTION}

The south-west of Western Australia is a biodiversity hotspot (Myers et al. 2000), with an extraordinary diversity of terrestrial animals and flowering plants, and high levels of regional endemism (Hopper et al. 1996; Hopper and Gioia 2004). Although most of south-western Western Australia is now dominated by xeric, semi-arid and transitional rainfall habitats (see Hopper and Gioia 2004), coastal and montane areas of the State's south and extreme south-west are profoundly influenced by Mediterranean winter rainfall and fickle Southern Ocean weather patterns, creating a mosaic of mesic habitats which are home to a distinctive and relictual southern-temperate invertebrate fauna. These mesic habitats in southwestern Western Australia are mostly restricted to the high-rainfall forested regions of the south coast, between Cape Leeuwin and Albany. Here, towering forests of Karri and Tingle (Eucalyptus spp.) provide refugial habitats very similar to those found in south-eastern Australia, and are home to several characteristically eastern Australian temperate lineages (e.g. Hopper et al. 1996; Main et al. 2002; Rix 2008). Beyond the tall eucalypt forests of the extreme south-west, truly mesic refugial habitats are more spatially isolated, usually restricted to coastal or uplifted landforms of higher altitude. Among the more obvious of these landforms are ancient coastal granitic peaks and the extraordinary mountains of the Stirling Range National Park, which capture moisture-laden clouds moving north from the Southern Ocean, creating wet montane heathlands and shaded, mesic gullies on southern slopes (Main 1999) (Figures 20-25). These small, largely isolated montane habitats are home to a remarkable diversity of short-range endemic species (Harvey 2002c), including many southerntemperate invertebrate taxa. Indeed, the peaks and south-facing gullies of the Stirling Ranges are renowned for their relictual invertebrate fauna, which includes spiders of the families Archaeidae and Migidae, along with many other arachnid, myriapod and gastropod taxa (see Hopper et al. 1996; Main 1999; Harvey 2002b, 2002c; Rix 2006; and references therein).

The Synotaxidae and Malkaridae are two families of small, entelegyne araneomorph spiders with similar, largely southern-temperate distributions: Synotaxidae currently includes 14 genera and 70 species from Australia, New Zealand, Chile and the neotropics; Malkaridae currently includes four genera and 10 species from Australia and Chile, along with many undescribed species from New Zealand (Platnick and Forster 1987; Platnick 2009). Both groups are most diverse in south-eastern Australia and New Zealand, where 11 genera of Synotaxidae and three genera of Malkaridae have so far been described (Platnick 2009).

The Australasian Synotaxidae were reviewed by Forster et al. (1990), who recognised two 
southern-temperate subfamilies: the Physogleninae, including four genera from Australia, New Zealand and Chile; and the Pahorinae, including five genera from New Zealand (Forster et al. 1990). Wunderlich (1994, 2008) described two additional synotaxid genera and three new species from south-eastern Queensland: Calcarsynotaxus longipes Wunderlich, 1994 from the Lamington Plateau, south of Brisbane; and most recently Microsynotaxus insolens Wunderlich, 2008 and M. calliope Wunderlich, 2008, both from Kroombit Tops, north of Brisbane.

The Australasian Malkaridae remain poorly studied, with a single species of Malkara Davies, 1980 described from south-eastern Queensland and two genera of Sternoidinae described from south-eastern Australia (Moran 1986; Platnick 2009). Spiders of the subfamily Sternoidinae are distinctive, highly sclerotised arachnids of the forest understorey: Perissopmeros Butler, 1932 includes six species from Victoria and New South Wales; Carathea Moran, 1986 includes two species from Tasmania (Moran 1986; Platnick 2009); and Chilenodes Platnick and Forster, 1987 includes a single species from Chile (Platnick and Forster 1987).

Recent field work in the eastern Stirling Range National Park of southern Western Australia (Figures 20-25) has revealed the presence of new species of Synotaxidae and Malkaridae, significantly extending the known distributions of these families in Australia. Calcarsynotaxus benrobertsi sp. nov. and Perissopmeros darwini sp. nov. are named on the occasion of the $200^{\text {th }}$ anniversary of the birth of Charles Darwin and the $150^{\text {th }}$ anniversary of the publication of On the Origin of Species. They represent the first records of Synotaxidae and Malkaridae in Western Australia, and highlight the importance of refugial montane habitats for the conservation of short-range endemic arachnids in southern Western Australia.

\section{MATERIAL AND METHODS}

The specimens examined as part of this study are lodged at the Western Australian Museum, Perth (WAM). Digital photographs were taken through a Leica MZ16A binocular microscope, and auto-montage images were captured using a Leica DFC500 mounted camera with Leica Application Suite version 2.5.0R1 software. Additional digital images were taken through an Olympus BH-2 compound microscope using a Q-Imaging Micropublisher 5.0 RTV mounted camera with Auto-Montage Pro imaging software by Syncroscopy. All specimens were described and illustrated in 75\% ethyl alcohol, and female abdomens were cleared in lactic acid or dissected and cleared in a gently-heated solution of $10 \%$ potassium hydroxide. Both male and female genitalia were illustrated on Utoplex tracing paper, using printed auto-montage template images taken through a compound microscope. ArcMap version 9.3.1 (ESRI Inc.) with Virtual Earth (Microsoft Corp.) was used to create the satellite image in Figure 24.

All measurements are in millimetres, and the following abbreviations are used throughout the text: ALE, anterior lateral eyes; ALS, anterior lateral spinnerets; AME, anterior median eyes; PLE, posterior lateral eyes; PME, posterior median eyes; PMS, posterior median spinnerets.

\section{SYSTEMATICS}

\section{Family Synotaxidae Simon, 1894}

Calcarsynotaxus Wunderlich, 1994

Calcarsynotaxus Wunderlich, 1994: 539.

\section{Type species}

Calcarsynotaxus longipes Wunderlich, 1994, by original designation.

\section{Calcarsynotaxus benrobertsi sp. nov.}

Figures 1-14

\section{Material examined}

Holotype

Australia: Western Australia: $\delta^{\lambda}$, Stirling Range National Park, Ellen Peak, summit (1007 m), $34^{\circ} 21^{\prime} 30^{\prime \prime}$ S, $118^{\circ} 19^{\prime} 57^{\prime \prime} \mathrm{E}, 6$ November 2007 , sifting elevated leaf litter under Lepidosperma sedges in montane Kunzea heathland, M. Rix et al. (WAM T96175).

\section{Paratypes}

Australia: Western Australia: allotype + , same data as holotype (WAM T96176); 1 O, 1 क, same data as holotype (WAM T89593); 1 ㅇ, Stirling Range National Park, south face of Pyungoorup Peak, 34 $21^{\prime} 54^{\prime \prime}$ S, $118^{\circ} 19^{\prime} 44^{\prime \prime}$ E, 5 August 2008, sifting elevated leaf litter under Lepidosperma sedges along mesic, shaded creek line, M. Rix, M. Harvey (WAM T94569).

\section{Affinities}

Calcarsynotaxus benrobertsi appears to be a member of the family Synotaxidae, in possessing an incised retrolateral margin of the cymbium, an excavate paracymbium and a complex terminal tegular sclerite on the male pedipalp (Agnarsson 2003; Figures 10-12). Other typically synotaxidlike characters include patellar macrosetae on the male pedipalp (Figures 10-12), an anterior stridulatory system on the male abdomen (Figures 8-9), large, rod-like fertilisation ducts (Figures 

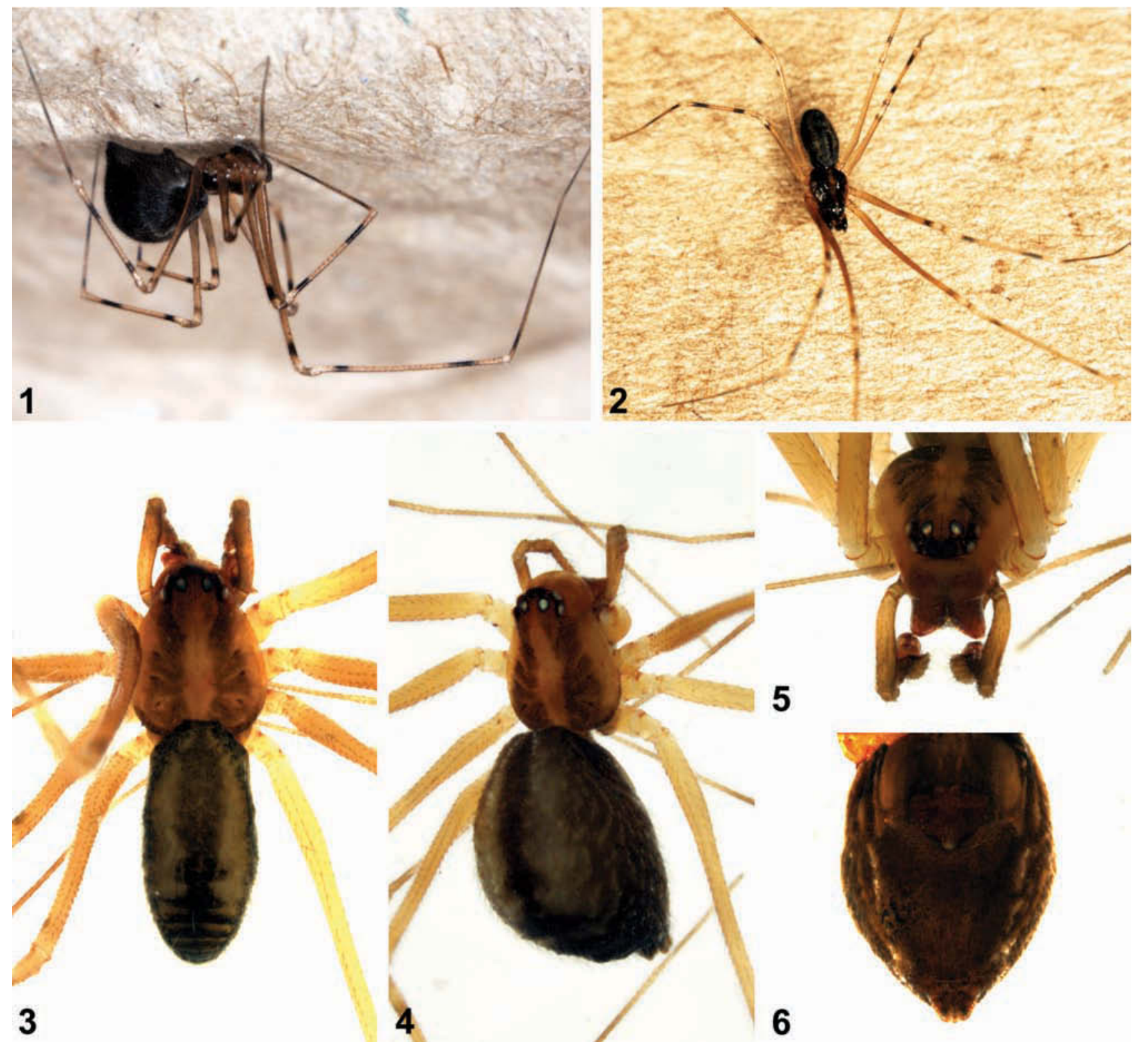

Figures 1-6 Calcarsynotaxus benrobertsi sp. nov., holotype male (WAM T96175) and allotype female (WAM T96176) from the Stirling Range National Park, Western Australia: 1, live female, lateral view; 2, live male, dorsal view; 3, male habitus, dorsal view; 4, female habitus, dorso-lateral view; 5, male cephalothorax, frontal view; 6, female abdomen, ventral view.

13-14), an external epigynal lobe (Figures 1, 6, 13-14), a domed, subtriangular female abdomen and elongate male abdomen (Figures 1-4), cuticular sculpturing on the male tegular sclerite (Figures 10-11), and modified anterior setae on the male ocular region (Figure 7).

Within the family Synotaxidae, the affinities of $C$. benrobertsi are unclear; the species does not possess the male abdominal stridulatory system characteristic of the subfamilies Physogleninae or Pahorinae, nor is it congeneric with the southeastern Australian physoglenine genera Тириа or Paratupua. The male pedipalpal morphology seems most similar to neotropical and South American species of Synotaxus and Chileotaxus (see Forster et al. 1990; Agnarsson 2003), although a phylogenetic analysis is required to determine whether this species is indeed more closely-related to New World taxa than to Australasian genera.

Calcarsynotaxus benrobertsi is similar to C. longipes (as described by Wunderlich 1994) in possessing a pair of very large, thorn-like macrosetae on the male pedipalpal patella (Figures 10,12) and a stridulatory system on the male abdomen antagonistic to the leg IV coxal region (Figures 8-9). However, the stridulatory system of $C$. benrobertsi is different to that described by Wunderlich (1994), in possessing a sternal 'opercular plate' over each leg IV coxa, rather than a coxal 'outgrowth'. The somatic morphology is also otherwise dissimilar to that described by Wunderlich (1994), suggesting placement in another, possibly new 

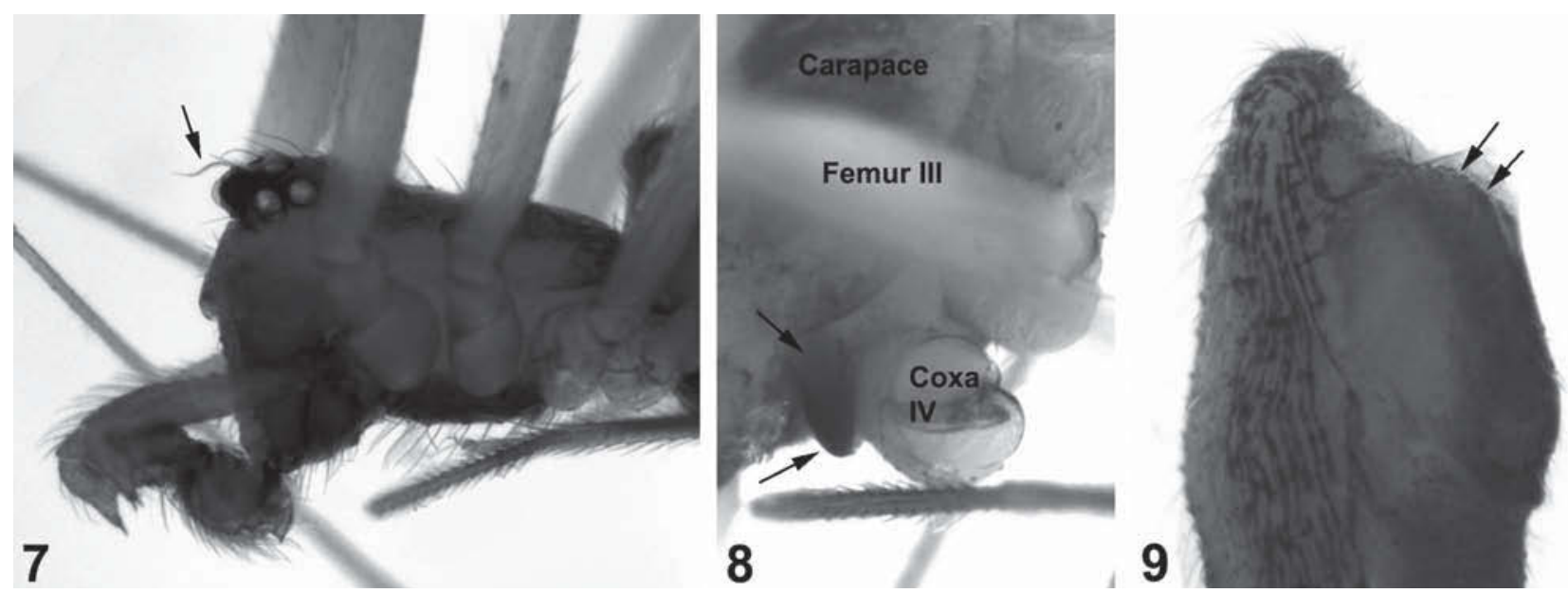

Figures 7-9 Calcarsynotaxus benrobertsi sp. nov., holotype (WAM T96175) and paratype (WAM T94569) males from the Stirling Range National Park, Western Australia: 7, holotype male cephalothorax, lateral view, showing ocular setae; 8 , paratype male carapace and coxa IV, postero-dorsal view, showing stridulatory 'opercular plate'; 9, paratype male anterior abdomen, lateral view, showing anterior tubercles and ridge of thickened cuticle.

synotaxid genus. In the absence of a phylogenetic hypothesis for the non-physoglenine/non-pahorine Synotaxidae of Australia, C. benrobertsi is hereby tentatively placed in the genus Calcarsynotaxus, although we acknowledge that this placement requires further testing.

\section{Diagnosis}

Calcarsynotaxus benrobertsi can be distinguished from all other Synotaxidae except $C$. longipes by the presence of two very large, thorn-like macrosetae on the male pedipalpal patella (Figures 10,12). The species can be distinguished from $C$. longipes by the longer, sinuous embolus (Figures 10-11) and the pronounced epigynal lobe with rod-like fertilisation ducts (Figures 1, 6, 13-14).

\section{Description}

\section{Holotype male}

Dimensions: total length 2.41; carapace 1.10 long, 0.88 wide; abdomen 1.58 long, 0.73 wide; leg I femur 3.63.

Colour: carapace tan-yellow, darker around ocular region and clypeus, with two longitudinal brown bands extending from posterior margin of carapace to PLE; legs tan-yellow, with darker brown bands on distal femora, proximal and distal tibiae, and proximal and distal metatarsi; sternum, chelicerae, pedipalps brown; abdomen cream with olive-brown cardiac mark, dark brown posterior chevrons, mottled dark brown markings laterally and olive-brown venter.

Carapace: relatively flat with raised ocular region; fovea triangular, pars thoracica with four weaklyincised furrows; setae present along midline of carapace and around eyes and clypeus, with pair of longer, sinuous, anteriorly-directed setae posterior to AME; clypeus broad, protruding anteriorly, with transversely incised furrow ventral to AME.

Eyes: eight, in two weakly-recurved rows; AME 0.06, ALE 0.08, PME 0.06, PLE 0.06; AME, lateral eyes paired; PME separated by their own diameter.

Sternum: longer than wide, posteriorly obtuse; cuticle of posterior sternum extending laterally around coxae of leg IV, covering each coxa with a thickened, ectal, operculum-like covering; each 'opercular plate' with dorsal stridulatory file.

Labium: rectangular, wider than long, fused to anterior margin of sternum.

Maxillae: directed across labium.

Chelicerae: rectangular, 2.5x longer than wide; promargin with three triangular teeth.

Abdomen: elongate, cylindrical, covered with short setae; cuticle thickened anterior to epigastric furrow, with tuberculate stridulatory ridges on either side of petiole interacting with 'opercular plates' of posterior sternum; broad posterior tracheal spiracle situated slightly anterior to colulus; colulus with two posteriorly-directed setae.

Spinnerets: six, posterior to colulus; ALS largest, PMS smallest.

Legs: longest to shortest I, II, IV, III; long (leg I femur-carapace ratio 3.3), three-clawed, covered in short setae; spines absent.

Pedipalp: patella with two very large, distal, thornlike macrosetae; tibia unmodified, rectangular; cymbium with incised retrolateral margin and short, excavate posterior paracymbium; bulb with large subtegulum and bulging tegulum; terminal tegular sclerite complex, consisting of tegular apophysis- and conductor-like portions (presumably homologous to the theridioid tegular 


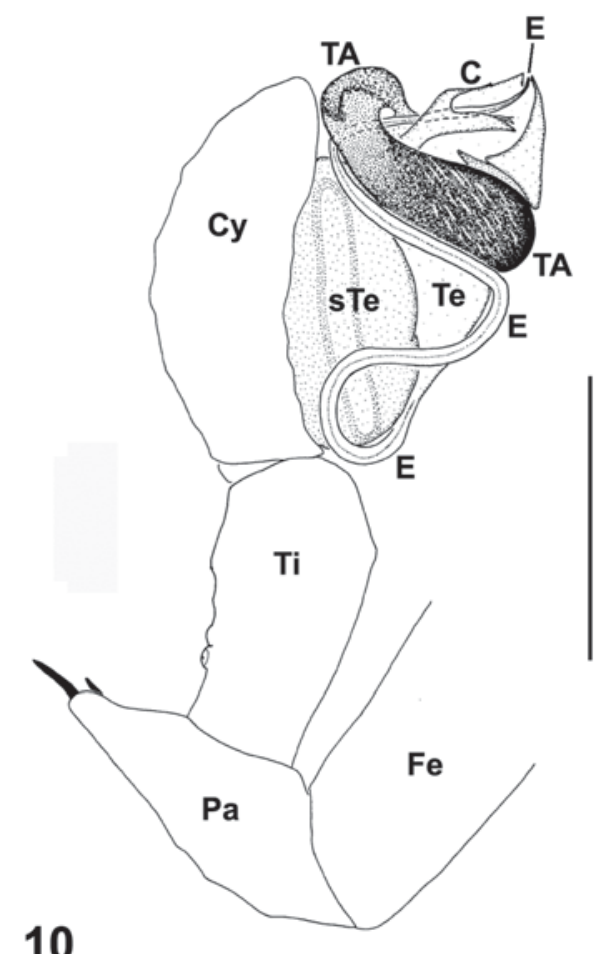

10

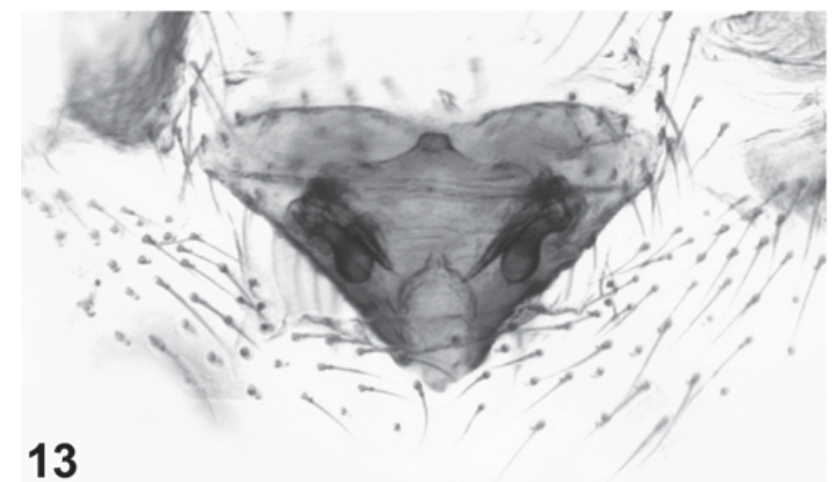

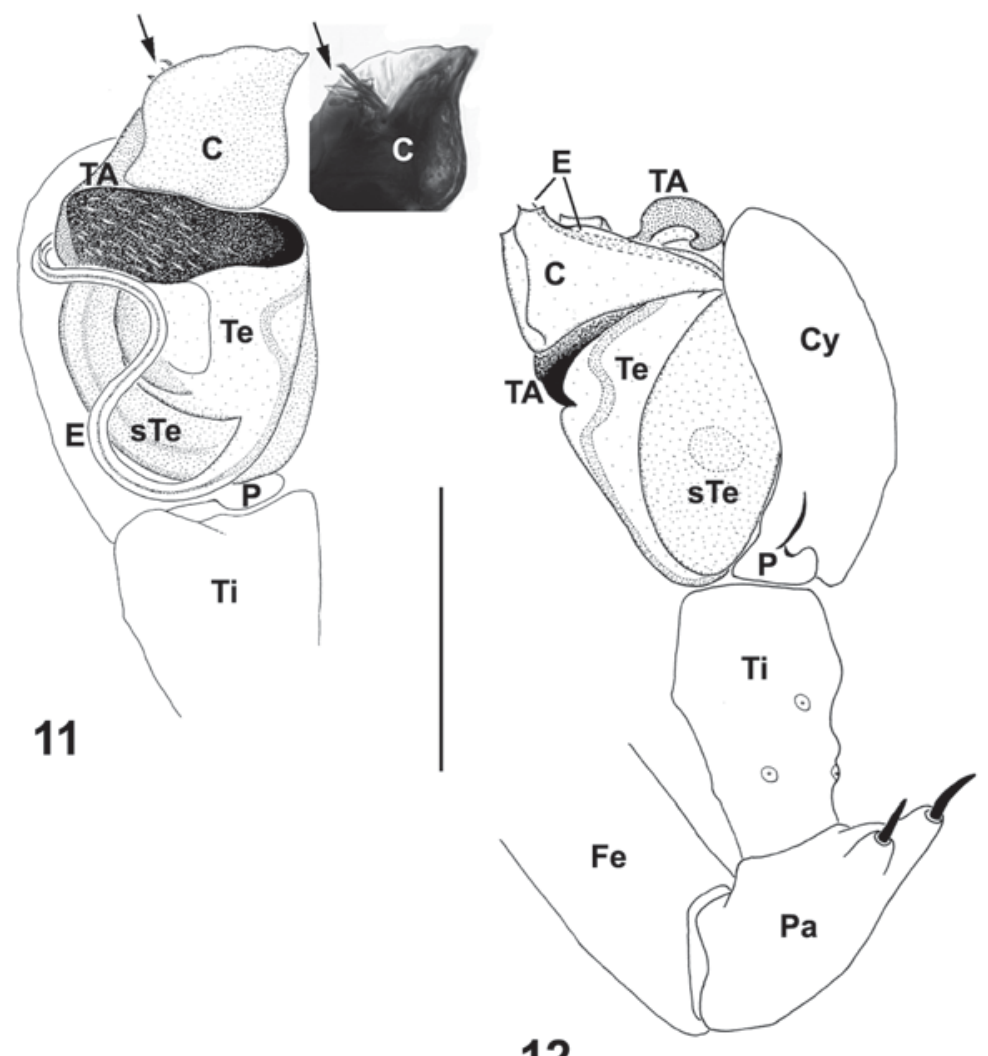

12

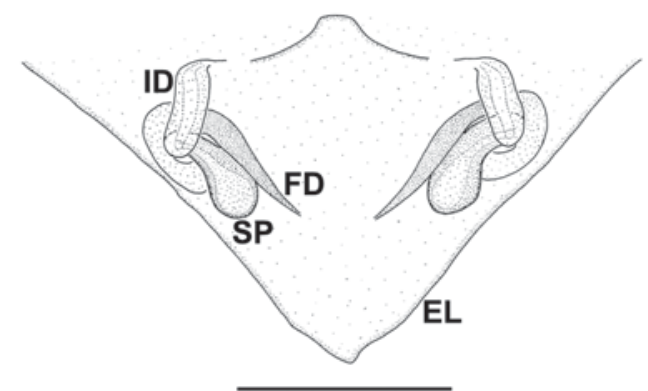

14

Figures 10-14 Calcarsynotaxus benrobertsi sp. nov., paratype male and female (WAM T94569) from the Stirling Range National Park, Western Australia: 10, male pedipalp, prolateral view; 11, male pedipalp, pro-ventral view, with inset showing equivalent compound microscope image of terminal conductor; 12, male pedipalp, retrolateral view; 13-14, cleared female receptacula, dorsal view. Note the paired, thorn-like macrosetae on the male pedipalpal patella, and the rod-like fertilisation ducts. $\mathrm{C}$, conductor; $\mathrm{Cy}$, cymbium; E, embolus; EL, epigynal lobe; FD, fertilisation duct; Fe, femur; ID, insemination duct; P, paracymbium; Pa, patella; SP, spermatheca; sTe, subtegulum; TA, tegular apophysis; Te, tegulum; Ti, tibia. Scale bars $=0.195 \mathrm{~mm}$ (Figures 10-12), $0.13 \mathrm{~mm}$ (Figure 14).

apophysis' described by Agnarsson 2003); tegular apophysis sinuous, dark, with cuticular sculpturing and hooked distal process; conductor broad, straddling embolus, with folded, spinous distal processes; embolus long, sinuous, extending around prolateral margin of bulb.

\section{Allotype female}

Dimensions: total length 2.80; carapace 1.17 long, 0.88 wide; abdomen 1.81 long, 1.22 wide; leg I femur 3.59 .
Colour: carapace tan-yellow, darker around ocular region and clypeus, with two longitudinal brown bands extending from posterior margin of carapace to PLE; legs tan-yellow, with darker brown bands on distal femora, proximal and distal tibiae, and proximal and distal metatarsi; sternum, chelicerae, pedipalps brown; abdomen cream with dark brown cardiac mark and posterior chevrons, olive brown striations laterally and olive-brown venter.

Carapace: relatively flat with raised ocular region; fovea triangular, pars thoracica with four weakly- 
incised furrows; setae present along midline of carapace and around eyes and clypeus; clypeus broad, protruding anteriorly.

Eyes: eight, in two weakly-recurved rows; AME 0.06, ALE 0.08, PME 0.08, PLE 0.06; AME, lateral eyes paired; PME separated by their own diameter.

Sternum: longer than wide, posteriorly obtuse; cuticle of posterior sternum extending laterally around coxae of leg IV, covering each coxa with an ectal, operculum-like covering; each 'opercular plate' smooth, without dorsal stridulatory file.

Labium: rectangular, wider than long, fused to anterior margin of sternum.

Maxillae: directed across labium.

Chelicerae: rectangular, $2.4 x$ longer than wide; promargin with three triangular teeth.

Abdomen: domed, subtriangular in lateral view, covered with short setae; without tuberculate cuticle either side of petiole; broad posterior tracheal spiracle situated slightly anterior to colulus; colulus with two posteriorly-directed setae.

Spinnerets: six, posterior to colulus; ALS largest, PMS smallest.

Legs: longest to shortest I, II, IV, III; long (leg I femur-carapace ratio 3.07), three-clawed, covered in short setae; spines absent; tibiae with two or three proximal trichobothria; metatarsi (legs I-III) with single trichobothrium; tarsal organ capsulate.

Pedipalp: entire, with elongate, curved distal claw without accessory teeth; tibia with three trichobothria.

Epigyne: receptacula fully-enclosed within large, bulbous-triangular epigynal lobe; intromittent pores situated ventrally near epigastric furrow; insemination ducts dorsally-looped, each leading to oval, posteriorly-directed spermatheca; fertilisation ducts large, rod-like, leading from ventral side of spermathecae around lateral margins of lobe.

\section{Distribution and Habitat}

Calcarsynotaxus benrobertsi was first discovered in November 2007, and is currently known only from the eastern massif of the Stirling Range National Park, on the summit of Ellen Peak and the south face of nearby Pyungoorup Peak (Figures 20-25). On both Ellen Peak and the south face of Pyungoorup Peak specimens were found living under the damp, shaded leaves of sedges (Lepidosperma spp., family Cyperaceae), in sympatry with two other spiders with very small distributions: the archaeid spider Austrarchaea robinsi Harvey, 2002b and the malkarid Perissopmeros darwini sp. nov. (see below).

\section{Etymology}

The specific epithet is a patronym for Benjamin
Roberts, evolutionary biologist with publications on speciation and sexual selection, who died unexpectedly, very early in his career.

\section{Family Malkaridae Davies, 1980}

\section{Subfamily Sternoidinae Harvey, 2002}

Sternodidae Moran, 1986: 88 (reduced to a subfamily of Malkaridae by Platnick and

Forster 1987: 9).

Sternoidinae Harvey, 2002a: 456.

Sternoidini Wunderlich, 2004: 1259. New synonymy.

\section{Remarks}

The family Sternodidae was proposed by Moran (1986) for the Australian genera Sternodes Butler, 1929 and Carathea Moran, 1986, but was reduced to a subfamily of Malkaridae by Platnick and Forster (1987). Sternodes was found to be preoccupied in Coleoptera (Platnick 1998) and replaced by Sternoides Platnick, 1998, which was then a junior subjective synonym of Perissopmeros Butler, 1932, itself formerly treated as a junior synonym of Sternodes (see Moran 1986). Harvey (2002a) proposed Sternoidinae as a replacement name for Sternodidae, as required under Article 39 of the International Code of Zoological Nomenclature (International Commission on Zoological Nomenclature 1999). Regrettably, a similar action was taken by Wunderlich (2004), thus rendering Sternoidini Wunderlich, 2004 a junior objective synonym and a homonym of Sternoidinae Harvey, 2002a, and we hereby synonymise the former.

\section{Genus Perissopmeros Butler, 1932}

Sternodes Butler, 1929: 50 (name preoccupied in Coleoptera).

Perissopmeros Butler, 1932: 116.

Sternoides Platnick, 1998: 226 (superfluous replacement name for Sternodes).

\section{Type species}

Perissopmeros: Perissopmeros castaneous Butler, 1932, by original designation.

Sternodes: Sternodes foraminatus Butler, 1929, by original designation.

Perissopmeros darwini sp. nov. Figures 15-19

\section{Material examined}

Holotype

Australia: Western Australia: ${ }_{\text {, }}$ Stirling Range 

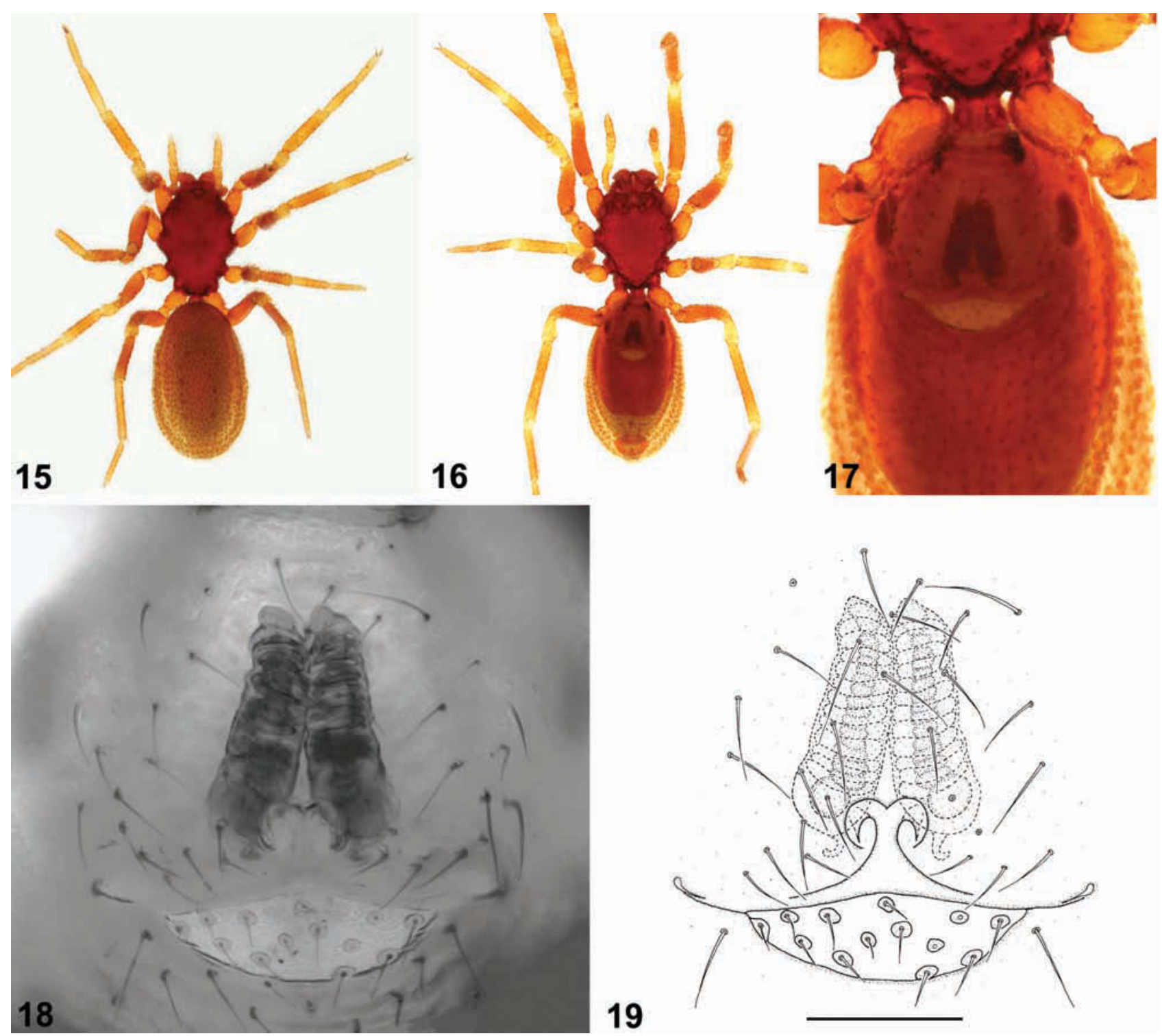

19

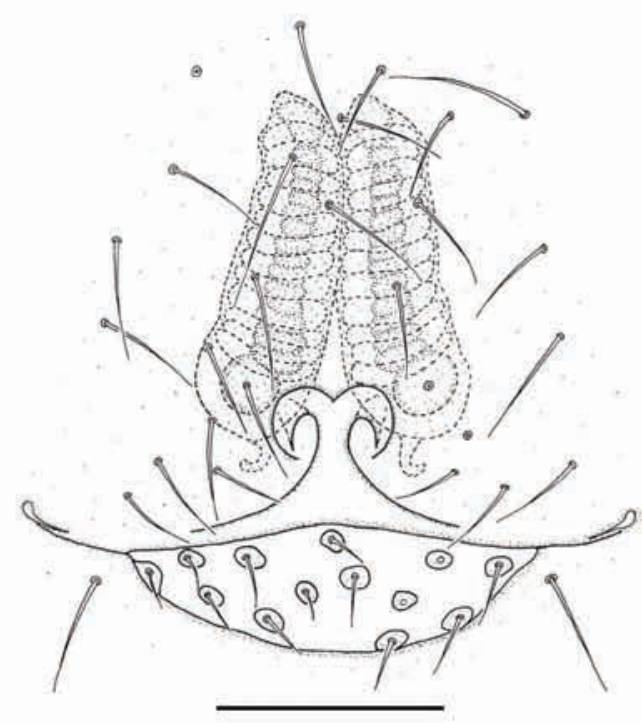

Figures 15-19 Perissopmeros darwini sp. nov., holotype female (WAM T89314) from the Stirling Range National Park, Western Australia: 15, habitus, dorsal view; 16, habitus, ventral view; 17, abdomen and external epigyne, ventral view, showing the elongate receptacula; $18-19$, receptacula, ventral view, showing the tightly coiled insemination ducts. Scale bar $=0.13 \mathrm{~mm}$ (Figure 19).

National Park, south face of Pyungoorup Peak, $34^{\circ} 21^{\prime} 54^{\prime \prime}$ S, $118^{\circ} 19^{\prime} 44^{\prime \prime}$ E, 27 April-4 September 1996, wet pitfall traps along mesic, shaded creek line, M. Harvey et al. (WAM T89314).

\section{Affinities}

Perissopmeros darwini appears to be a member of the genus Perissopmeros as described by Moran (1986), in possessing relatively tightly-coiled insemination ducts (Figures 18-19). The species is, however, more similar to the Tasmanian genus Carathea in not possessing ocular 'horns' (see Moran 1986), although this character is absent in other sternoidine species from Victoria (pers. obs.), and is even subject to intraspecific variation in Chilenodes (see Platnick and Forster 1987). Given the possible homoplasy in the presence or otherwise of ocular projections, and thus the possible paraphyly of the genus Carathea with respect to Perissopmeros, $P$. darwini is tentatively placed in the latter genus, pending a phylogenetic analysis of the subfamily.

\section{Diagnosis}

Perissopmeros darwini can be distinguished from all other described sternoidine species in the genera Perissopmeros, Carathea and Chilenodes by the presence of elongate receptacula and highly coiled insemination ducts which rotate anteriorly at least 12 times (Figures 18-19).

\section{Description}

\section{Holotype female}

Dimensions: total length 2.35; carapace 0.96 long, 

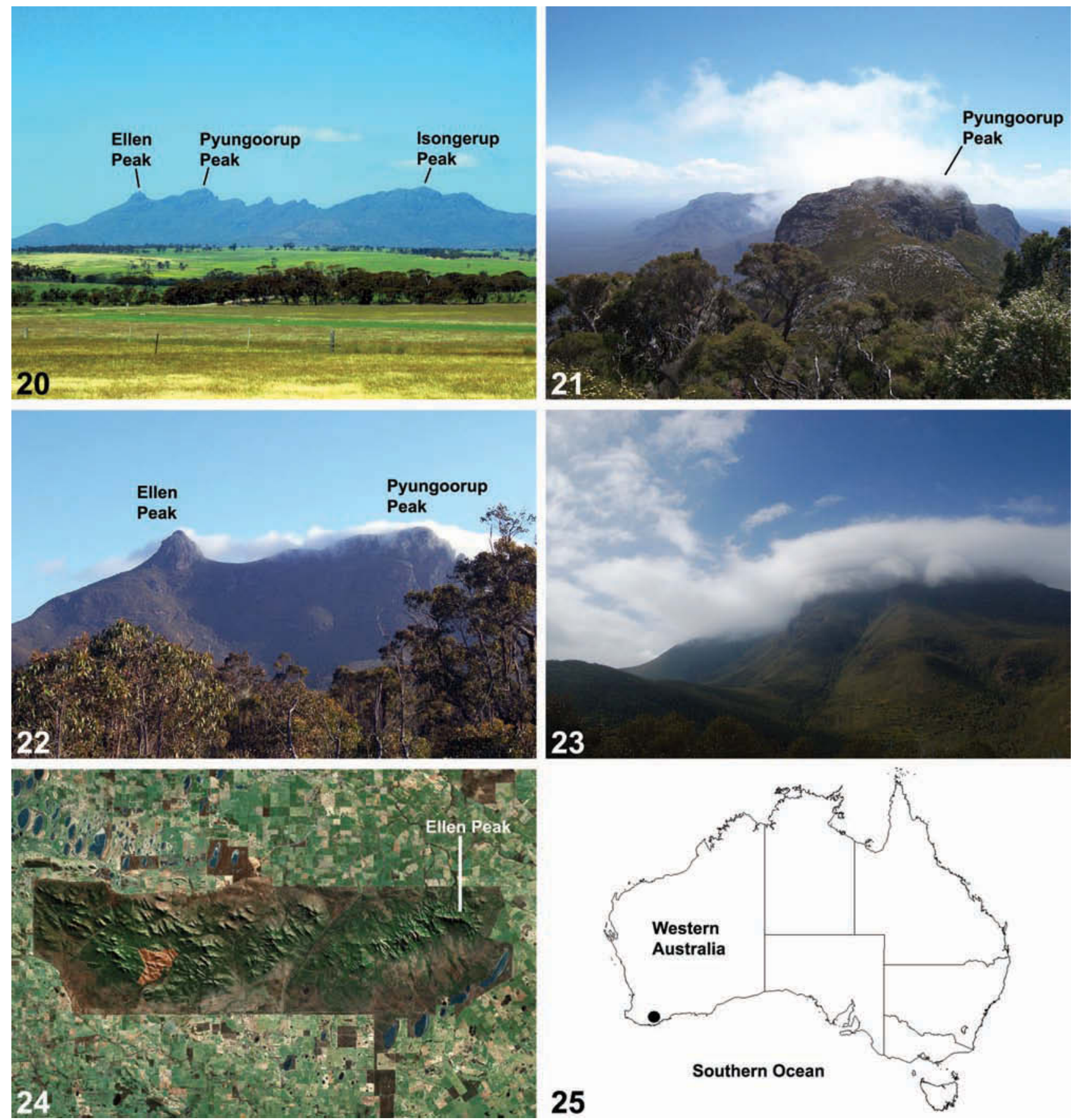

Figures 20-25 The Stirling Range National Park, south-western Western Australia - home to Calcarsynotaxus benrobertsi sp. nov. and Perissopmeros darwini sp. nov.: 20, view from the north of the eastern massif, showing Ellen, Pyungoorup and Isongerup Peaks; 21, montane heathland on the summit of Ellen Peak, looking west from the type locality of $C$. benrobertsi; 22, late-afternoon cloud forming over the summit of Ellen Peak and nearby Pyungoorup Peak; 23, early-morning cloud and fog covering Bluff Knoll and the Stirling Range's eastern massif, as seen from north-west of Bluff Knoll; 24, satellite image of the Stirling Range National Park, showing the position of Ellen Peak and the eastern massif; 25, map of Australia, showing the location of the Stirling Range National Park. Images $20-23$ by M. Rix.

0.66 wide; abdomen 1.33 long, 0.78 wide; leg I femur 0.74 .

Colour: carapace, sternum, chelicerae dark orange; legs, pedipalps tan-yellow; abdomen cream with orange sclerotic spots, orange anterior sclerite and orange posterior sclerotic ring around spinnerets.

Carapace: roughly diamond-shaped in dorsal view, with pronounced lateral extensions around coxae of legs; pars cephalica smoothly raised, without ocular 'horns'; pars thoracica with rim of conical, setal tubercles laterally; cuticle of carapace heavily punctate, with pair of large, deeply excavate glandular depressions on either side of carapace above maxillae. 
Eyes: eight, situated antero-dorsally on unmodified anterior margin of pars cephalica; internally separated from exocuticle due to preservation.

Sternum: longer than wide, posteriorly pointed, fully fused to carapace via pleural sclerites; cuticle coarsely tuberculate.

Labium: triangular, slightly longer than wide, fused to anterior margin of sternum.

Maxillae: rectangular, anteriorly directed.

Chelicerae: rectangular, $2 x$ longer than wide; promargin excavate with one proximal tooth; retromargin with row of four teeth.

Abdomen: oval, slightly flattened in lateral view, covered with short setae; each seta projecting from small sclerotic spot; seven medial pairs of sigillae present on dorsal surface; anterior sclerite very large, heavily sclerotised, covering most of ventral surface of abdomen, with unsclerotised foramen posterior to epigastric furrow; posterior sclerotic ring surrounding spinnerets and colulus, with ventral slit-like tracheal spiracle.

Spinnerets: six, posterior to colulus; ALS largest, PMS smallest.

Legs: longest to shortest IV, I, II, III; relatively short (leg I femur-carapace ratio 0.77), threeclawed, covered in short setae; superior claws of legs I and II strongly pectinate; spines absent; tibiae with two (leg I), three (legs II-III) or four (leg IV) trichobothria; metatarsi each with single trichobothrium; tarsal organ capsulate.

Pedipalp: entire, tarsus longer than tibia, with elongate, curved distal claw without accessory teeth.

Epigyne: receptacula elongate, clearly visible externally; spermathecae rounded, situated posteriorly above intromittent pores; insemination ducts long, tightly coiled, rotating anteriorly at least 12 times; fertilisation ducts short, curved.

\section{Distribution and Habitat}

Perissopmeros darwini was first discovered in 1996, during a series of pitfall trapping surveys in the Stirling Range National Park. The species is currently known only from the eastern massif of the Stirling Range, on the south face of Pyungoorup Peak (Figures 20-25). The type locality is a shaded, mesic creek line, also home to Calcarsynotaxus benrobertsi sp. nov. (see above) and the archaeid spider Austrarchaea robinsi.

\section{Etymology}

The specific epithet is a patronym in honour of Charles Darwin (1809-1882), author of On the Origin of Species and co-proposer of the theory of evolution by natural selection. The year 2009 marks the $200^{\text {th }}$ anniversary of Darwin's birth, and the $150^{\text {th }}$ anniversary of the publication of On the Origin of Species (published 24 November 1859).

\section{ACKNOWLEDGEMENTS}

This research was funded by the Department of Terrestrial Zoology at the Western Australian Museum, and the authors would like to thank Volker Framenau and Julianne Waldock (Western Australian Museum, Perth), along with Barbara Main (University of Western Australia), Janet Newell, Polly Mitchell, Nicole Moore, Alan Danks, Sarah Comer, Sarah Barrett and Deon Utber (all Department of Environment and Conservation, Albany) for assistance during field work in the Stirling Range National Park.

\section{REFERENCES}

Agnarsson, I. (2003). The phylogenetic placement and circumscription of the genus Synotaxus (Araneae: Synotaxidae), a new species from Guyana, and notes on theridioid phylogeny. Invertebrate Systematics 17: 719-734.

Butler, L.S.G. (1929). Studies in Australian spiders, No. 1. Proceedings of the Royal Society of Victoria 42: 41-52.

Butler, L.S.G. (1932). Studies in Australian spiders, No. 2. Proceedings of the Royal Society of Victoria 44: 103-117.

Davies, V.T. (1980). Malkara loricata, a new spider (Araneidae: Malkarinae) from Australia (377-382). In: Gruber J. (ed.), Verhandlungen 8. Internationaler Arachnologen-Kongress: H. Egerman: Wien.

Forster, R.R., Platnick, N.I. and Coddington, J. (1990). A proposal and review of the spider family Synotaxidae (Araneae, Araneoidea), with notes on theridiid interrelationships. Bulletin of the American Museum of Natural History 193: 1-116.

Harvey, M.S. (2002a). Nomenclatural notes on Solifugae, Amblypygi, Uropygi and Araneae (Arachnida). Records of the Western Australian Museum 20: 449-459.

Harvey, M.S. (2002b). A new species of Austrarchaea (Araneae: Archaeidae) from Western Australia. Records of the Western Australian Museum 21: 35-37.

Harvey, M.S. (2002c). Short-range endemism among the Australian fauna: some examples from non-marine environments. Invertebrate Systematics 16: 555-570.

Hopper, S.D. and Gioia, P. (2004). The southwest Australian floristic region: evolution and conservation of a global hot spot of biodiversity. Annual Review of Ecology, Evolution and Systematics 35: 623-650.

Hopper, S.D., Harvey, M.S., Chappill, J.A., Main, A.R. and Main, B.Y. (1996). The Western Australian biota as Gondwanan heritage - a review (1-46). In: Hopper, S.D., Chappill, J.A., Harvey, M.S. and George, A.S. (eds), Gondwanan Heritage: Past, Present and Future of the Western Australian Biota: Surrey Beatty and Sons: Chipping Norton, NSW.

International Commission on Zoological Nomenclature (1999). International Code of Zoological Nomenclature, fourth edition. International Trust for Zoological Nomenclature: London. 
Main, B.Y. (1999). Biological anachronisms among trapdoor spiders reflect Australia's environmental changes since the Mesozoic (236-245). In: Ponder, W. and Lunney, D. (eds), The Other 99\%. The Conservation and Biodiversity of Invertebrates: Transactions of the Royal Zoological Society of New South Wales: Mosman, NSW.

Main, B.Y., Harvey, M.S. and Waldock, J.M. (2002). The distribution of the Western Australian pill millipede, Cynotelopus notabilis Jeekel (Sphaerotheriidae). Records of the Western Australian Museum 20: 383-385.

Moran, R.J. (1986). The Sternodidae (Araneae: Araneomorpha), a new family of spiders from eastern Australia. Bulletin of the British Arachnological Society 7: 87-96.

Myers, N., Mittermeier, R.A., Mittermeier, C.G., da Fonseca, G.A.B., and Kent, J. (2000). Biodiversity hotspots for conservation priorities. Nature (London) 403: 853-858.

Platnick, N.I. (1998). Advances in Spider Taxonomy 1992-1995, with Redescriptions 1940-1980. New York Entomological Society: New York.

Platnick, N.I. (2009). The World Spider Catalog, Version 9.5. American Museum of Natural History, New York, online at: http://research.amnh.org/entomology/ spiders/catalog/INTRO1.html (accessed 1 March 2009).
Platnick, N.I. and Forster, R.R. (1987). On the first American spiders of the subfamily Sternodinae (Araneae, Malkaridae). American Museum Novitates 2894: 1-12.

Rix, M.G. (2006). Systematics of the Australasian spider family Pararchaeidae (Arachnida: Araneae). Invertebrate Systematics 20: 203-254.

Rix, M.G. (2008). A new species of Micropholcomma (Araneae: Araneoidea: Micropholcommatidae) from Western Australia. Records of the Western Australian Museum 24: 343-348.

Simon, E. (1894). Histoire Naturelle des Araignées. Libraire Encyclopédique de Roret: Paris, Tome 1(3): 489-760.

Wunderlich, J. (1994). Description of the new genus Calcarsynotaxus from Australia (Arachnida: Araneae: Synotaxidae). Beiträge zur Araneologie 4: 539-542.

Wunderlich, J. (2004). Fossil pirate spiders (Araneae: Araneoidea: Mimetidae s. l.) in Baltic and Dominican amber, with notes on intrafamilial higher taxa. Beiträge zur Araneologie 3B: 1249-1278.

Wunderlich, J. (2008). Descriptions of a cryptic fossil and enigmatic extant genus of the family Synotaxidae. Beiträge zur Araneologie 5: 130-139.

Manuscript received 25 March 2009; accepted 13 August 2009. 